\title{
MYH9 wt Allele
}

National Cancer Institute

\section{Source}

National Cancer Institute. MYH9 wt Allele. NCI Thesaurus. Code C97648.

Human MYH9 wild-type allele is located in the vicinity of 22q13.1 and is approximately $107 \mathrm{~kb}$ in length. This allele, which encodes myosin-9 protein, plays a role in both cytokinesis and cell shape. Mutation of the gene is associated with May-Hegglin anomaly, non-syndromic sensorineural deafness autosomal dominant type 17, Epstein syndrome, Sebastian syndrome, Fechtner syndrome and macrothrombocytopenia with progressive sensorineural deafness and non-diabetic end stage renal disease. A chromosomal translocation $\mathrm{t}(2 ; 22)(\mathrm{p} 23 ; \mathrm{q} 12)$ of this gene and the ALK gene is associated with anaplastic large cell lymphoma. 